\title{
The Strategic Orientation of Entrepreneurship on The Small and Medium Business At Batik Kudus As A Heritage Culture
}

\author{
Nafi' Inayati Zahro ${ }^{1}$, Sutono ${ }^{2}$, Noor Latifah ${ }^{3}$ \\ \{nafi'.inayati@umk.ac.id ${ }^{1}$, sutono@umk.ac.id ${ }^{2}$, noor.latifah@umk.ac.id ${ }^{3}$ \} \\ 1,2,3 Universitas Muria Kudus, Gondang Manis PO. BOX 53 Bae, Kudus, Central Java, Indonesia Phone \\ (+62291) 438229, Fax (+62291)437198
}

\begin{abstract}
Kudus is a small town with a variety of diversity found in the community. In the city of Kudus there are also 2 Sunan namely "Sunan Muria" and "Sunan Kudus". Sunan Kudus himself left a teaching "Gusjigang", which is an acronym for "bagus, ngaji, dagang". This philosophy motivates Kudus residents in trading and entrepreneurship, in Kudus the trade and SME sectors are the economic drivers and one of the backbone of the economy of Kudus Regency, including Kudus Batik. The Kudus Batik Industry is an industry that elevates the local wisdom culture of the "Local Wisdom" of Kudus Regency, in terms of its motives raising the local culture and the folklore of Kudus into a uniqueness \& distinctiveness compared to other batik. In the product development program, the theme of the sacred batik was focused on activities (1) Marketing and management training, (2) Digital marketing training, (3) Batik application training and assistance with J Batik Digital Program, (4) Production Improvement, (5) Marketing Expanses.
\end{abstract}

Keywords: Batik, marketing, production, management, SMEs

\section{INTRODUCTION}

Kudus is a small town with a variety of diversity found in the community. Starting from religion, work, trade, to culture. In the city of Kudus, there are also 2 Sunan of Walisongo who spread Islam on the ancient island of Java. Sunan Kudus himself left a teaching "Gusjigang". Gusjigang is an acronym for "bagus, ngaji dan dagang". Gus means good, ji means the pray, gang means trade. In terms of good morals, diligently reciting the Qur'an, and good at trading. Gusjigang itself has been firmly attached to the life of the Kudus community. From this philosophy that motivates the citizens of Kudus in trading and entrepreneurship, it's no wonder that in Kudus the trade and SME sectors are the economic drivers and one of the backbone of the Kudus Regency's economy. Among them are UKM Batik Kudus, Kudus Batik expected to be popular from 1880 - Just like batik in other coastal areas such as Pekalongan batik, Jepara batik, Pati batik and Lasem batik, Kudus batik also has bright colors with unique motifs that are so distinctive. One thing that distinguishes Kudus batik from other batik is the cultural 
acculturation between Chinese, indigenous, and Islamic elements. 1940 and developed until 1970.

Local wisdom is a product of the past culture that should be continuously used as a guide for life. Although the wisdom is local, the values contained in it are universal. The source of the value of local wisdom comes from religious values, or religion in general, in addition to the values learned by humans from nature. These values are accepted by the community and used as a way of life (Sartini, 2009: 9-10). Batik art is one of the results of culture known since the ancestors. Batik is highly admired not only for its complicated processes but also in its unique and beautiful motifs and colors, which are full of symbolic meanings (Indarmaji 1983: 123).

One of the Batik UKM that started to develop now is in Gebog sub-district, precisely in the villages of Gribig and Karangmalang with a fairly bright export prospect. The UKM is Alfa Shoofa with its design that lifts traditional arts and stories - the history of Kudus city has a pretty bright export prospect.

Batik craftsman must be able to read market trends that are developing at this time, not to supply abundant similar products, but must be able to develop different designs or motifs that have particular characteristics, especially not mutually imitating each other. One of the classic problems in developing batik is that the color of batik is still monotonous, dominated by dark colors and tends to be black or brown.

Management of business management that is still low is also one of the problems in UKM Batik. Financial structuring and financial records from UKM UKM are still done simply like a family business. Corporate finance is still mixed with owner's finances. There are no accounting / financial programs / software yet used to record cash inflow and cash outflow and budget preparation. Tax obligations have been fulfilled by SMEs, but sometimes it becomes a separate obstacle due to the lack of understanding of taxation procedures, the current problem is the government requires employers to fill SPT on line which for SMEs themselves are still having difficulty in filling e-filling and how to access them.

Most of the capital operated by the majority of UKM UKM is own capital. Most SMEs do not understand the procedure for lending to banks. Without financial reports prepared according to PSAK standards by SMEs, SMEs will have difficulty accessing loans to banks. Through guidance and assistance from the government of research and technology (RISTEK DIKTI) through the regional superior product development program (PPPUD) through universities team on an ongoing basis to be able to increase production capacity, production quality, improvement management, marketing, environment and other aspects.

\section{IMPLEMENTATION AND METHODS}

The implementation of the activities of the Regional Superior Product Development Program for the second year will be carried out starting in February 2019 at UKM partners, UKM Alfa Shoofa. The methods used in carrying out the Batik Kudus Regional Superior Product Development program in Kudus Regency, Central Java Province, are (1) Marketing and management training, (2) Digital marketing training, (3) Batik application training and assistance with J Batik Digital Program, (4) Production Improvement, (5) Marketing Expanses

\section{RESULTS AND DISCUSSION}


This community service activity is aimed at increasing the production of Batik as well as developing towards the Regional Superior Products of Kudus Batik in Mitra UKM, namely UKM in the Alfa Shoofa Batik craft industry. The results of the activities that have been carried out include:

\section{Marketing management training}

The aim of the training and mentoring is to provide insight for partner SMEs in innovating products in the form of goods, services, ideas. Improving the quality and quality of Kudus batik because consumers will love the products that offer the best quality, the best performance and the best traits so that Alfa SMEs must focus on continuous product improvement, like products that are easily available and very affordable, therefore management must focus on improving production efficiency and distribution

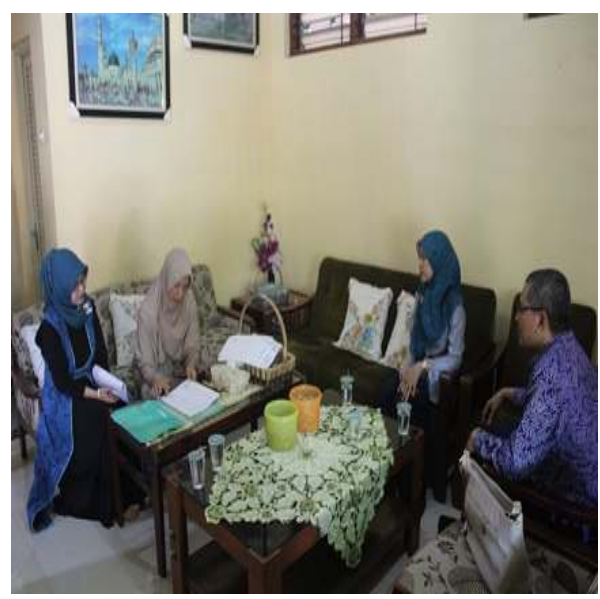

Fig 1. Marketing management accompaniment

\section{Digital Marketing Training}

This digital marketing training workshop was carried out with the theme "On Line Business Training" with UKM Alfa Shoofa participants and also invited SMEs in Kudus district. This activity brought in expert digital marketing experts from Bukalapak. Digital marketing is now a trend that is starting to develop in the world of entrepreneurship. Almost everyone around the world uses internet services for their daily needs. This makes a great opportunity that can used by partner SMEs to reach a wider market. To develop its market SMEs must plunge into cyberspace and have special tricks to be able to lure more customers to buy this Kudus batik product. But there is a major problem faced by SMEs, which is that they are still constrained in the field of technology. The purpose of this training and mentoring activity is expected that SMEs especially SMEs of Kudus Batik service partners can open their horizons about the digital world and can start marketing their products to all corners of the 
world, so as to increase the export activities of Holy Batik, and open the way to become SMEs worldwide.

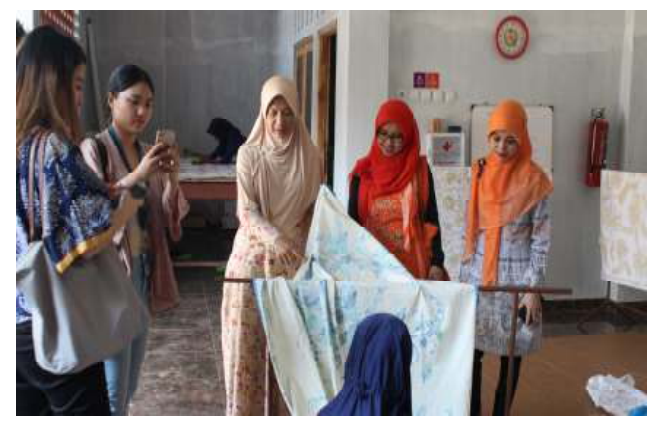

Fig 2. Accompaniment in PPPUD team activities

\section{Batik application training and assistance with J Batik}

So far, the batik SMEs only know that the process of making batik patterns can only be done with canting and a piece of cloth, but now along with the development of information technology software has been developed to design batik, one of which we introduce to UKM Alfa Shoofa and Muria batik is J - Batik software. With jBatik design software, the process of making batik patterns can be done by mapping batik patterns mathematically which will then be translated into digital batik patterns by batik software with jBatik. Even with just one pattern when combined with other patterns in jBatik can produce new batik patterns (Elam, 2001).

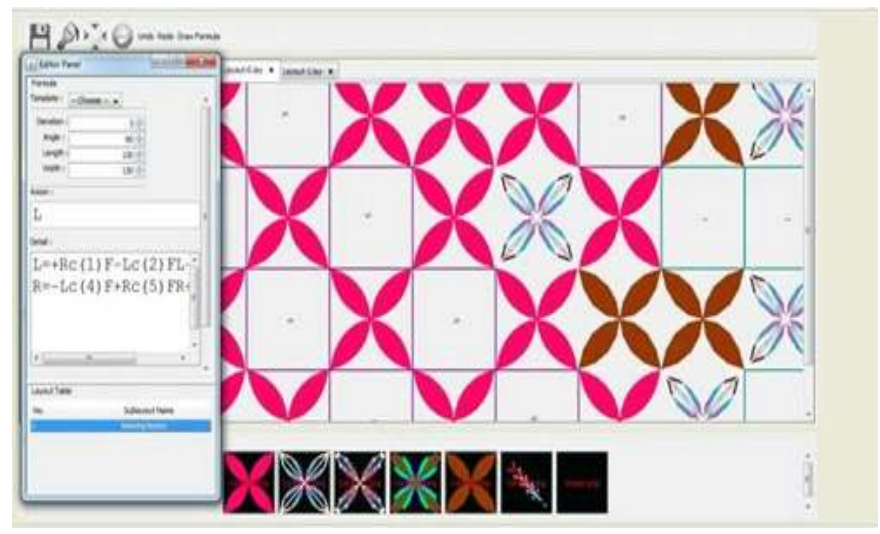

Fig 3. Create Pattern with J-Batik Program 


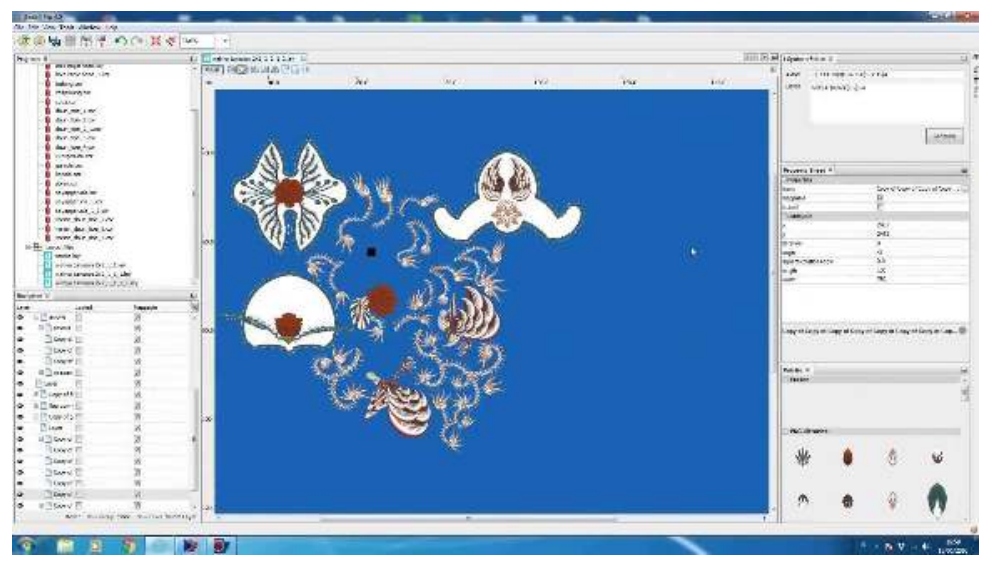

Fig 4. Layout and Edit with J-Batik

\section{Production Improvement}

In order to improve production and increase production capacity, the service program is enhanced by: (1) supplying two electric stoves for written batik for each UKM as many as two, with the following specifications: Power: 125 Watt, voltage: 220 Volt, and working temperature: $600 \mathrm{C}-900 \mathrm{C}$.

(2). Procurement of "kenceng tembaga", kenceng tembaga is useful as a cloth container in the process of releasing wax night on the fabric by dipping in boiling water, this copper kenceng is needed by SMEs. Its in the "pelorodan" process in addition to its large capacity compared to the drum, because so far in the two SMEs washing process still use drums, while these drums have many disadvantages of which often experience leaks, so often replace the drum and instead lead to waste.

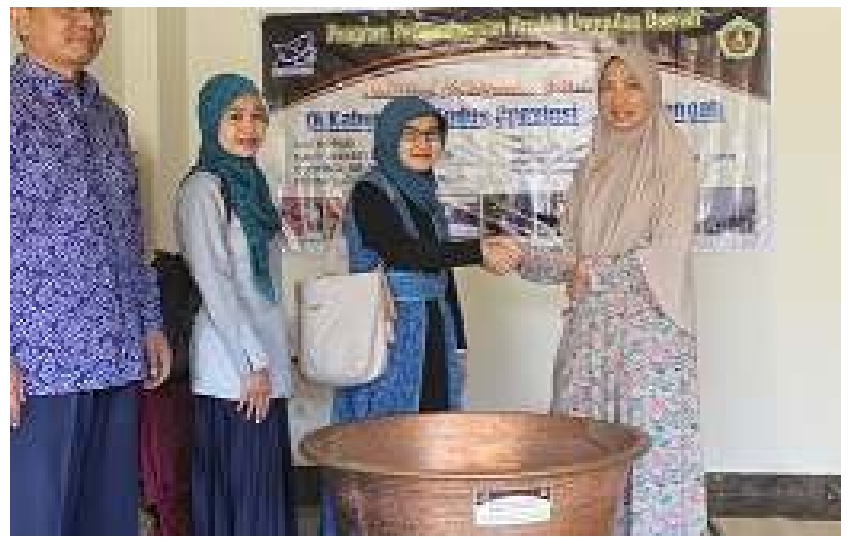

Fig 5. "Kenceng Tembaga" from PPPUD team investment to production in Batik Kudus 


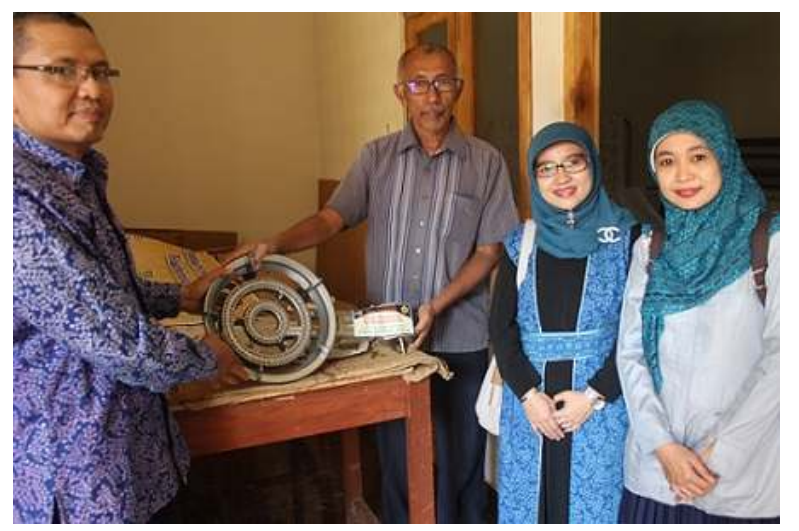

Fig 6. Production tool from PPPUD team

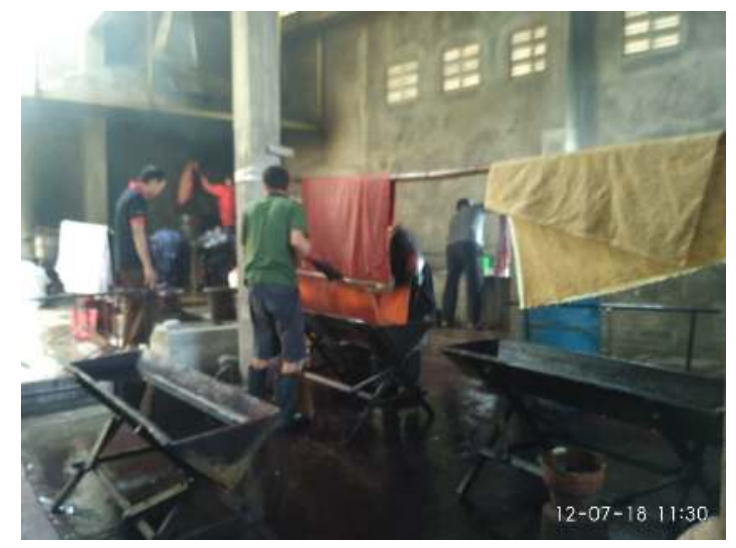

Fig 7. "Pelorodan" Process in Production Kudus Batik Crafts Industries

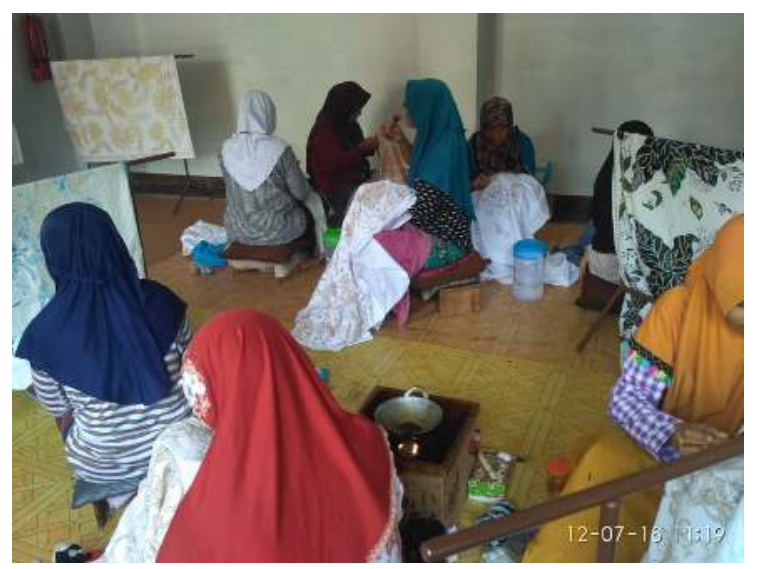

Fig 8. The Process called "Mencanting" 


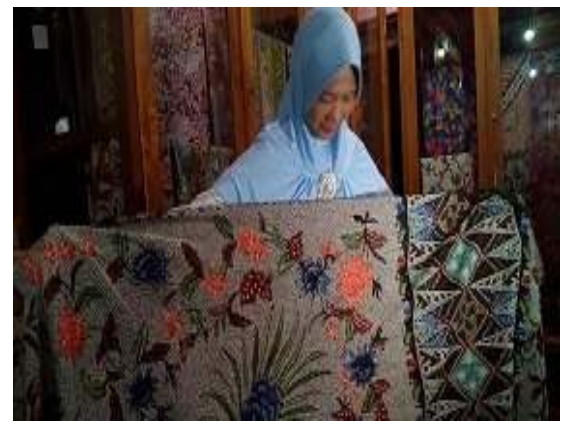

Fig 9. Result of batik Kudus crafts

\section{Marketing Expanses}

In the context of marketing expansion, among others, it is done by improving and developing marketing through the website. In addition, in order to increase product sales turnover by participating in exhibitions both at home and abroad, including in Malaysia taking part in the Indonesia Creative Product Festival at the Kuala Lumpur Malaysia Putra Word trade center, Muslim Fashion Festival, Civex Exhibition in Batam, Riau, Exhibition at JCC Senayan, following the Indonesian Fashion Chamber, and also through coverage in television and print media. In an effort to expand the market network, the PPPE team has also prepared brochures, business cards and product catalogs.

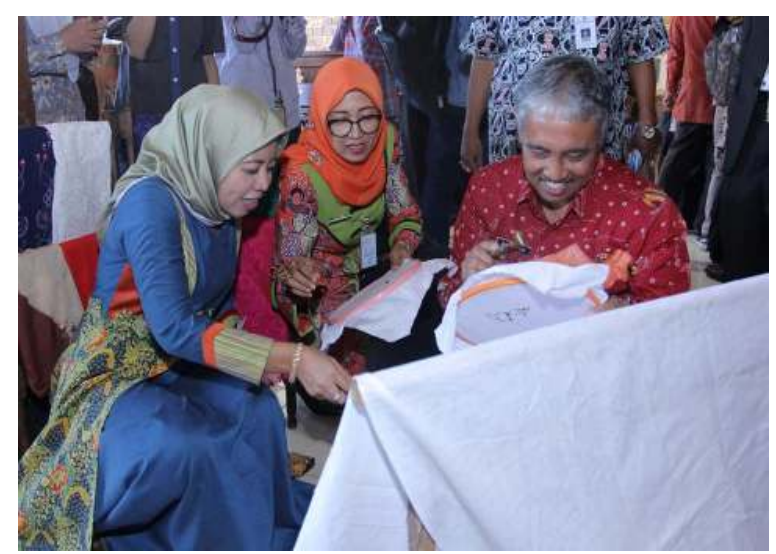

Fig 10. Batik Kudus Exhibition 


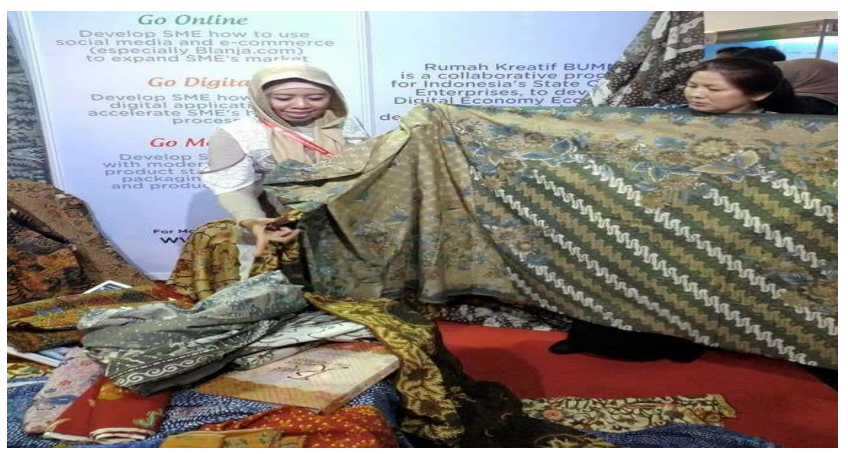

Fig 11. Batik Kudus Exhibition in Foerign Country

\section{CLOSING}

\subsection{Conclusion}

1. The service activities of the Export Batik Development Program have provided benefits for SME Partners namely Alfa Shoofa Batik. The PPPUD program in the first year focused on increasing production, improving administrative management, and marketing. From the PPPUD service program activities, investment in tools for each partner has been given, namely copper plates and electric stoves, as well as accounting and inventory sales and accounting software. The productivity of each SME partner has also increased, production capacity has increased, sales have also increased, so that the turnover has also increased.

2. Market expansion of each SMEs has also increased, getting customers from various regions, agencies, and also exporting to various countries both directly and indirectly, including to Malaysia, Singapore, Brunei, and Korea. Marketing expansion was also carried out by participating in both national and international expo events, through exhibitions in several cities including Jakarta, Semarang, Batam, Bali, as well as overseas expos in Kuala Lumpur Malaysia. Besides collaborating with the local government of the Kudus district, the industry and trade service, the Cooperative and SMEs service, the BUMN, also cooperated with wellknown designers such as Denny Wirawan and Ivan Gunawan. The introduction of Kudus batik through mass media both print and television, through TV station coverage, has been broadcast on MNC and metro TV.

3. Human resources capacity has also increased, in addition to training provided to improve the quality of human resources as well as the number of employees has also increased, in addition to improving the welfare of employees at UKM Batik has been registered on health social security to protect the health of its employees.

4. With the improvement and improvement of aspects of management, financial management and administration have also been carried out well, with the implementation of a sales system using computerization and financial records and inventories with computer 
applications make financial statements can be arranged properly according to Financial Accounting standards so that it can be known profit and definite business costs.

\section{REFERENCES}

[1]. Indarmaji. 1983. Seni Kerajinan Batik. Dinas Pariwisata Daerah Istimewa Yogyakarta.

[2]. Sartini, N. W. (2009). Menggali Nilai Kearifan Lokal Budaya Jawa Lewat ungkapan (Bebasan, Saloka, dan Paribasa). Jurnal Ilmiah dan Sastra. (5) 1, 28-37.

[3]. Elam, Kimberly., (2001). Geometry of Design, Studies in Proportion and Composition, Princeton Architectural Press, New York.

\section{THANK-YOU NOTE}

With regard to the implementation of PPPE program of Kudus Batik Craft Industry in Kudus Regency of Central Java Province, we would like to extend our greatest thanks to:

1. Directorate of Research and Community Service Directorate General Strengthening Research and Development Ministry of Research, Technology and Higher Education for the funding provided so that PPPE program of Batik Kudus craft can run well.

2. Rector of Muria Kudus University with permission and direction given in the implementation of this program.

3. Chairman of LPPM Muria Kudus University for the direction and encouragement given during this and in the future.

4. Both partner SMEs are SMEs Alfa Shoofa and SME Muria Batik for cooperation and participation during this and in the future. 